\section{POS1341 TOCILIZUMAB FOR THE TREATMENT OF IMMUNE- RELATED ADVERSE EVENTS TO IMMUNE CHECKPOINT INHIBITORS: A CASE SERIES}

C. Campochiaro ${ }^{1}$, N. Farina ${ }^{1}$, A. Tomelleri', G. De Luca ${ }^{1}$, G. Cavalli ${ }^{1}$, C. Lazzari', R. Ferrara ${ }^{3}$, M. Garassino ${ }^{3}$, V. Gregorc ${ }^{2}$, L. Dagna ${ }^{1} .{ }^{1} I R C C S$ San Raffaele Hospital, Unit of Immunology, Rheumatology, Allergy and Rare Diseases, Milan, Italy; ${ }^{2}$ RRCCS San Raffaele Hospital, Department of Oncology, Division of Experimental Medicine, Milan, Italy; ${ }^{3}$ Fondazione IRCCS Istituto Nazionale dei Tumori, Medical Oncology Department, Milan, Italy

Background: Immune checkpoint inhibitors (ICl) are pharmacological agents effectively used in the treatment of several malignant tumors. The hyperactivation of the immune system induced by $\mathrm{ICl}$ may trigger an inflammatory involvement of healthy tissues, a phenomenon referred to as immune-related adverse event (irAE). No clinical trials are available to guide the management of irAEs. Observational data suggest tocilizumab might be effective in severe cases of irAEs, but data are scant. The possibility of continuing $\mathrm{ICI}$ treatment despite the development of irAE and the subsequent initiation of tocilizumab has never been evaluated. Objectives: To evaluate the efficacy and safety of tocilizumab, as monotherapy or alongside the continuation of $\mathrm{ICl}$ treatment, in the management of irAEs. Methods: We retrospectively identified patients who developed irAEs and were referred to our specialized Clinic between May 2018 and December 2020. Among these patients, we identified those who had been treated with tocilizumab and collected information about their oncologic history and outcome, ICl therapy and irAEs. Results: Thirty-nine patients were referred to our outpatient Clinic following the development of irAEs. Five of them were treated with tocilizumab. Disease and demographic features are reported in Table 1. At irAEs onset all patients were treated with glucocorticoids. A steroid-sparing agent was started to permit an adequate prednisone tapering without the irAE relapsing. Before tocilizumab start, two patients were treated with methotrexate monotherapy, one with anakinra monotherapy, and one with methotrexate and anakinra combination therapy. A significant therapeutic effect was confirmed in all patients and no significant adverse reactions were reported. $\mathrm{ICl}$ therapy was permanently discontinued in two patients. In the other three cases, cancer immunotherapy was safely continued alongside tocilizumab without further irAEs occurring. Only one patient experienced tumor progression two years after $\mathrm{ICl}$ suspension and subsequently died despite the improvement of his myocardial inflammatory involvement.

Conclusion: In our cohort, tocilizumab proved to be an effective and safe therapy for the management of irAEs.

Our case series also supports the possibility of maintaining $\mathrm{ICl}$ while introducing tocilizumab for irAE treatment. This combined approach might represent a suitable therapeutic option to guarantee a significant anti-inflammatory activity without losing the oncologic response.

REFERENCES:

[1] Kostine M et al, Ann Rheum Dis, 2021;80:36-48.

Table 1. Clinical characteristics of patients who developed irAEs secondary to ICI therapy and who received tocilizumab.

\begin{tabular}{|c|c|c|c|c|c|}
\hline & Patient 1 & Patient 2 & Patient 3 & Patient 4 & Patient 5 \\
\hline $\begin{array}{l}\text { Age at irAE onset } \\
\text { (years) }\end{array}$ & 69 & 52 & 72 & 57 & 75 \\
\hline Sex & Male & Male & Male & Female & Female \\
\hline $\begin{array}{l}\text { Neoplastic } \\
\text { histology }\end{array}$ & NSCLC & NSCLC & NSCLC & NSCLC & $\begin{array}{c}\text { Pleural meso- } \\
\text { thelioma }\end{array}$ \\
\hline $\mathrm{ICl}$ treatment & Nivolumab & Nivolumab $\mathrm{F}$ & Pembrolizumab & Pembrolizumab & Pembrolizumab \\
\hline irAE & Myocarditis & $\begin{array}{l}\text { Arthritis } \\
\text { Cutaneous } \\
\text { vasculitis }\end{array}$ & Arthritis & Arthritis & $\begin{array}{c}\text { Large vessel } \\
\text { vasculitis }\end{array}$ \\
\hline $\begin{array}{l}\mathrm{ICI} \text { discontinua- } \\
\text { tion due to irAE }\end{array}$ & Yes & No & No & No & Yes \\
\hline $\begin{array}{l}\text { PDN initial dose } \\
\text { (mg daily) }\end{array}$ & 50 & 37.5 & 25 & 25 & 37.5 \\
\hline DMARD therapy * & $\begin{array}{c}\text { T16: ANK } \\
\text { T20: TCZ } \\
\text { T26: TCZ + } \\
\text { MMF }\end{array}$ & $\begin{array}{c}\text { T5: MTX } \\
\text { T6: } \text { MTX + } \\
\text { ANK } \\
\text { T11: MTX + } \\
\text { TCZ }\end{array}$ & $\begin{array}{c}\text { T3: MTX } \\
\text { T11: MTX + } \\
\text { TCZ }\end{array}$ & $\begin{array}{c}\text { T4: MTX } \\
\text { T6: } \mathrm{MTX}+\mathrm{TCZ}\end{array}$ & T3: TCZ \\
\hline irAE outcome & Improvement L & $\begin{array}{c}\text { Low disease } \\
\text { activity }\end{array}$ & $\begin{array}{c}\text { Low disease } \\
\text { activity }\end{array}$ & Remission & Remission \\
\hline $\begin{array}{l}\text { Follow-up length } \\
\text { (months) }\end{array}$ & $\begin{array}{l}50 \\
10\end{array}$ & $\begin{array}{l}47 \\
25\end{array}$ & $\begin{array}{c}57 \\
2\end{array}$ & $\begin{array}{c}25 \\
5\end{array}$ & $\begin{array}{c}26 \\
8\end{array}$ \\
\hline $\begin{array}{l}\text { Since oncologic } \\
\text { diagnosis } \\
\text { Since TCZ start }\end{array}$ & & & & & \\
\hline $\begin{array}{l}\text { Oncological } \\
\text { outcome }\end{array}$ & $\begin{array}{l}\text { Progressive } \\
\text { disease } \\
\text { and death }\end{array}$ & $\begin{array}{l}\text { Complete } \\
\text { response }\end{array}$ & Stable disease & Stable disease & $\begin{array}{l}\text { Complete } \\
\text { response }\end{array}$ \\
\hline
\end{tabular}

* Treatment chronology is referred to as a $T$ followed by the number of months since irAE onset. ANK, anakinra; $\mathrm{ICl}$, immune checkpoint inhibitor; irAE, immune-related adverse events: DMARD, disease modifying anti-rheumatic drug; MTX, methotrexate; NSCLC, non-small cell lung cancer; PDN, prednisone; TCZ, tocilizumab.
Disclosure of Interests: Corrado Campochiaro Speakers bureau: Novartis, Pfizer, Roche, GSK, SOBI, Nicola Farina: None declared, Alessandro Tomelleri: None declared, Giacomo De Luca Speakers bureau: SOBI, Novartis, Celgene, MSD, Pfizer, Giulio Cavalli Speakers bureau: SOBI, Chiara Lazzari: None declared, Roberto Ferrara: None declared, Marina Garassino: None declared, Vanesa Gregorc: None declared, Lorenzo Dagna Speakers bureau: Abbvie, Amgen, Biogen, BMS, Celltrion, Novartis, Pfizer, Roche, SG, SOBI, Celgene Janssen, MSD, MP

DOI: 10.1136/annrheumdis-2021-eular.1253

\section{POS1342 1 CHEMOPROPHYLAXIS IN LATENT TUBERCULOSIS ASSOCIATED WITH RHEUMATIC IMMUNE-MEDIATED DISEASES. STUDY OF 240 PATIENTS FROM A SINGLE UNIVERSITY HOSPITAL}

D. Martínez-López ${ }^{1}$, J. Rueda-Gotor ${ }^{1}$, J. Osorio-Chavez ${ }^{1}$, C. Álvarez-Reguera ${ }^{1}$, V. Portilla ${ }^{1}$, M. A. González-Gay ${ }^{1}$, R. Blanco ${ }^{1} .{ }^{1}$ Hospital Universitario Marqués de Valdecilla, Rheumatology, Santander, Spain

Background: Tuberculosis (TB) may be increased with biologic therapy (BT). Diagnosis and treatment of latent TB infection (LTBI) is the best strategy to prevent TB. In Rheumatic Immune-Mediated Diseases (R-IMID) and LTBI, chemoprophylaxis must be used before BT. The drugs more frequently used are Isoniazid (INH), Rifampicin (RIF) and Fluoroquinolones (FQ). These drugs may be associated with side-effects, especially hepatotoxicity.

Objectives: To assess, in a single University Hospital, a) used chemoprophylactic drugs and, b) adverse events with these drugs.

Methods: We included all consecutive patients in the last five years (2016-2020) with a diagnosis of R-IMID and a positive LTBI test (positive tuberculin skin tes and/or interferon- $\gamma$-release assay), who received chemoprophylaxis prior to BT. Dose of chemoprophylactic drugs were a) INH ( $5 \mathrm{mg} / \mathrm{kg} / \mathrm{d}$, maximum, $300 \mathrm{mg}$; fo 9 months with vitamin B6), b) RIF (10 mg/ $/ \mathrm{kg} / \mathrm{d}$, maximum, $600 \mathrm{mg}$ for 4 months) and c) FQ levofloxacin ( $500 \mathrm{mg} /$ day for 9 months).

In all patients analytic controls that included liver enzymes were performed at the 1 st and 3rd month and then at a variable time.

Results: 240 patients were analyzed ( 165 women/ 75 men), mean age of $56 \pm 11$ years. The underlying R-IMID of patients receiving chemoprophylaxis were rheumatoid arthritis $(n=74,30.8 \%)$, axial spondyloarthritis $(n=59,24.6 \%)$, psoriatic arthritis $(n=62,25.8 \%)$, conectivopathies $(n=17,7.1 \%)$, vasculitis $(n=12,5 \%)$, sarcoidosis $(n=2,0.8 \%)$, Behçet's disease $(n=1,0.4 \%)$, inflammatory myopathies $(n=1,0.4 \%)$ and other $(n=12,5 \%)$.

At the onset of chemoprophylaxis they were taking: Prednisone in 61 patients (24 of them above $10 \mathrm{mg} /$ day) and the following conventional DMARD, methotrexate $(n=109,45.4 \%)$, hydroxychloroquine $(n=20,8.3 \%)$, sulfasalazine $(n=11,4.6 \%)$, leflunomide $(n=4,1.7 \%)$ and azathioprine $(n=2,0.8 \%)$.

The first-line chemoprophylactic drug was INH in 232 (96.7\%) patients and RIF in the remaining $8(3.3 \%)$. Due to adverse events, second-line therapy was used in 18 (RIF, $n=17$ and Levofloxacin, $n=1$ ) patients previously treated with INH. Adverse events were more frequent with $\mathrm{INH}$, being observed in 55 patients $(23.7 \%$ ) out of 232. (Table 1 next page, Figure 1 below). By contrast, only 1 out of $25(4 \%)$ receiving RIF presented an adverse event, which was hepatotoxicity, requiring suspension of RIF. No adverse events were described in the only patient receiving levofloxacin.

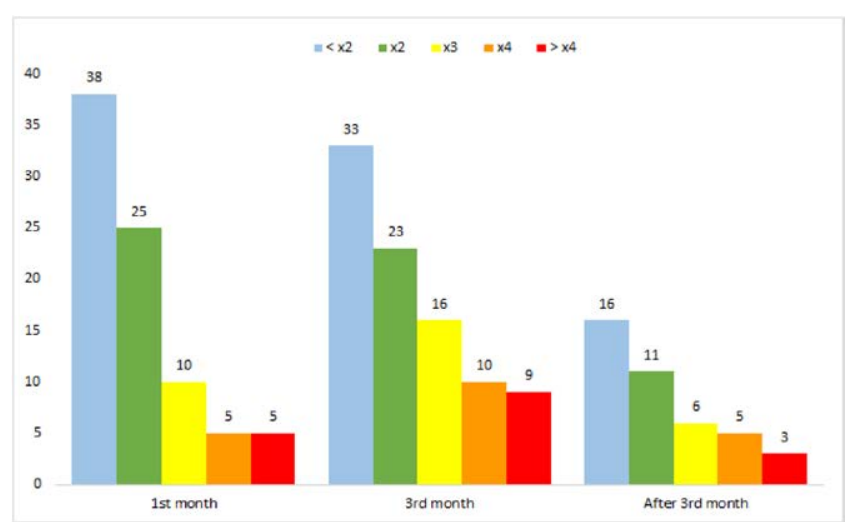

Figure 1. Liver enzyme elevation over baseline in patients in treatment with isoniazid.* Patients with higher liver enzyme elevation are included in the previous groups.

Conclusion: INH is the most used first-line treatment for LTBI. RIF was mainly used as second-line therapy if an adverse event with INH was observed. Treatment was generally well tolerated and most adverse events did not require the withdrawal of the treatment. Hepatotoxicity was the most frequent adverse event with $\mathrm{INH}$ and the most frequent cause of treatment withdrawal. 